\title{
BLOCOS DE TERRA COMPACTADA DE SOLO- CIMENTO COM RESÍDUO DE ARGAMASSA DE ASSENTAMENTO E REVESTIMENTO: CARACTERIZAÇÃO PARA USO EM EDIFICAÇÕES
}

FABÍOLLA XAVIER ROCHA FERREIRA LIMA, Dra. | UFG PAULO CASTILHO LIMA, Dr. | UnB

\section{RESUMO}

A tese surgiu da necessidade de aprofundamento na pesquisa sobre blocos de solo-cimento como material alternativo de construção, com uma análise a partir da visão da arquitetura, e não só da construção civil, observando o problema da moradia no Brasil e, além disso, em busca de soluções que contribuíssem com a preservação do meio ambiente. Uma vez que para a construção de novas moradias grande quantidade de recursos naturais são extraídos de forma indiscriminada e também causam significativa geração de resíduos, sugere-se a incorporação de resíduo de argamassa de cimento e areia, proveniente do assentamento e revestimento de paredes (Figura 1), na produção de blocos de solo-cimento, denominado BTC (bloco de terra compactada) de SCR (solo-cimento-resíduo). Com finalidade de uso para fechamentos e vedações verticais de moradias de interesse social, foram realizados estudos, ensaios e análises de desempenho técnico dos blocos moldados (Figura 2). Atentando-se para a originalidade da pesquisa, foram estudados traços com $12,5 \%$ de cimento e $0 \%, 20 \%$, $40 \%$ e $60 \%$ de resíduo em substituição à massa de solo. O procedimento experimental abrangeu a definição das dosagens dos traços, a preparação e caracterização das amostras de solo, das amostras de cimento, amostras do resíduo e a caracterização físico-mecânica dos BTCsSCR, por meio dos ensaios de absorção e durabilidade, ambos aos 7 dias, e resistência à compressão simples aos 7 e 28 dias de idade.

Os resultados mostram que todos os traços com resíduo são indicados para confecção de BTC-SCR, porém, o traço que obteve melhores resultados foi aquele com 20\% de resíduo (Figura 3).

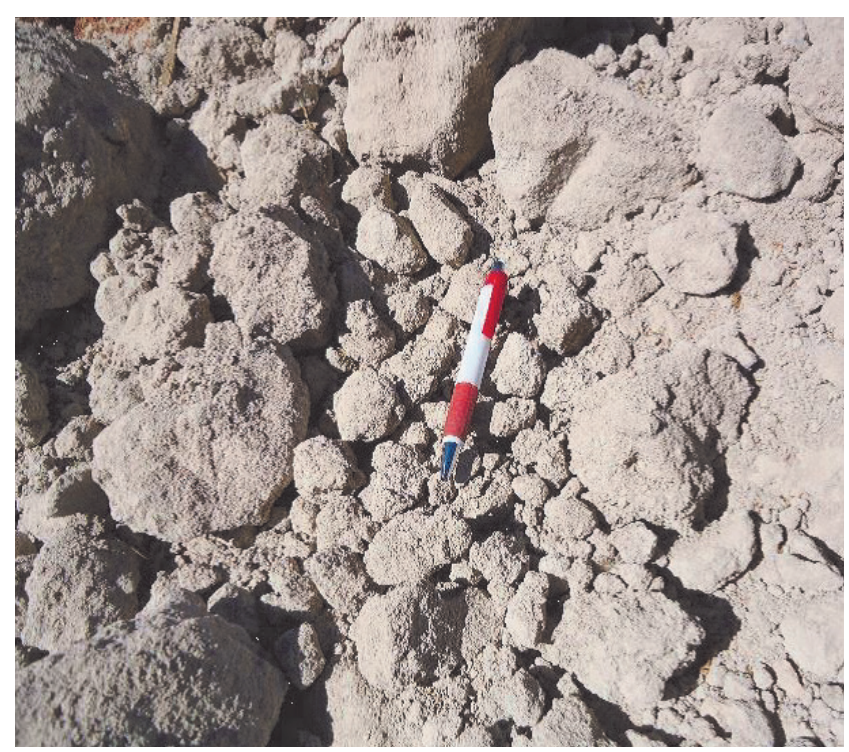

Figura 1 - Resíduo de argamassa de cimento e areia coletado em canteiro de obra Fonte: Autora

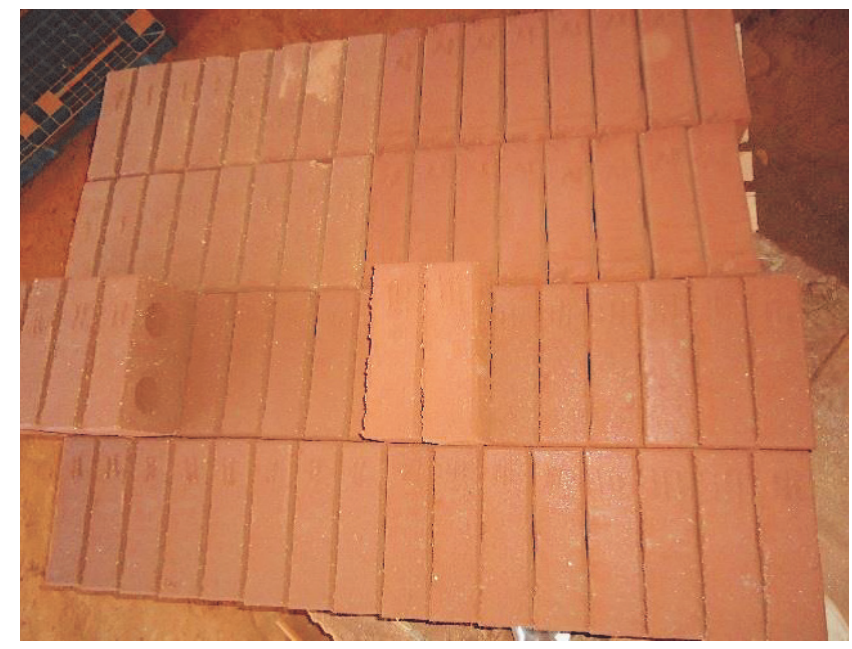

Figura 2 - Blocos moldados para cura Fonte: Autora 


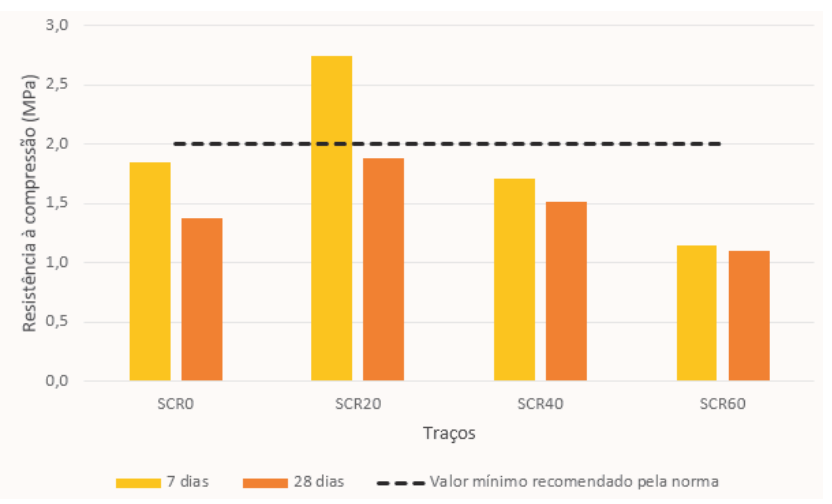

Figura 3 - Resistência à compressão simples aos 7 e 28 dias Fonte: Autora

Em termos gerais, considera-se a substituição do solo pelo resíduo mais uma alternativa econômica e sustentável para a produção de componentes construtivos que atendam aos critérios de coordenação modular, resistência mecânica, capacidade de absorção de água e durabilidade, necessários ao bom desempenho ambiental e de conforto das edificações, especialmente moradias de baixo custo. 